Testing Merton's Model for Credit Spreads on Zero-Coupon Bonds

Gordon Gemmill 


\title{
Testing Merton's Model for Credit Spreads on Zero-Coupon Bonds
}

by

Gordon Gemmill

Faculty of Finance

City University Business School

Frobisher Crescent

Barbican Centre

London EC2Y 8HB

(44) (0) 207-040-8743

g.gemmill@city.ac.uk

March 2002

\begin{abstract}
$\underline{\text { Abstract }}$
Structural models for valuing corporate bonds (beginning with Merton (1974)) have been criticised for giving spreads which are (a) too small and (b) have a term structure in which spreads diminish with extra time to maturity. Empirical tests of models are hampered by the complexity of real-world bonds, which have coupons, calls and sinking funds, and also by the complicated and changing capital structures adopted by companies. This paper exploits a new database of zero-coupon bonds issued by closed-end funds in the UK. These companies have very simple capital structures and transparent values for both assets and liabilities. Between 20 and 78 bonds are observable monthly over the period February 1992 to April 2001. Counter to previous research, we find that model and market spreads are on average of similar magnitude. Similar to previous research, market spreads are high (relative to model spreads) for bonds which have low risk and for bonds which are near to maturity. While the observed term-structure of credit spreads is upward-sloping, this may be explained by a predictable drift in leverage over time. On the whole, the results are surprisingly supportive of Merton's model and suggest that it is important to allow for expected changes in leverage when computing credit spreads.
\end{abstract}

Keywords: spread, bond, credit-risk, Merton, closed-end fund.

The author gratefully acknowledges the assistance provided by Sachin Shah on the preliminary analysis for this paper. 


\section{Testing Merton's Model for Credit Spreads on Zero- Coupon Bonds}

\section{$\underline{\text { 1. Introduction }}$}

Yields on corporate bonds exceed those on equivalent government bonds by an amount known as the credit spread. The factors which affect the spread are: the probability of default, the loss if there is a default, the taxation of corporate bonds relative to government bonds, and the systematic risk of corporate bonds (Elton et al, 2001). Models of the spread then combine these factors in different ways. Structural models (following Black and Scholes, 1973 and Merton, 1974) use an option-pricing approach which brings together systematic risk, probability of loss and recovery rate into a put option on the value of the firm. Reduced-form models (such as those of Jarrow and Turnbull, 1995, and Duffie and Singleton, 1999) base their results on exogenous hazard rates (often based on transition probabilities of ratings) and the loss on default, so they do not explicitly consider firm value or leverage.

Structural models are intuitively appealing but have proved rather difficult to implement. The main problem is that the companies and their bonds are more complicated than the textbook models. Although 15,000 corporate bonds may be sampled in the US, this number is reduced to about 50 after firms with complicated structures have been eliminated (see e.g. Eom, Helwege and Huang, 2000). The bonds are also coupon-paying, so each has to be valued as a portfolio of zero-coupon bonds (with each coupon being an individual component).

The objective of this paper is to apply Merton's structural model to a sample of unusually simple corporate bonds in the UK, to see whether there are systematic differences between observed (market) spreads and model spreads. The sample is exceptional because the bonds have no coupons, the companies have only one issue of bonds and each company is liquidated at the bond's maturity. In addition, because these are financial companies, they are obliged to publish the market value of their assets at least once per month. The companies are known as split-capital closed-end funds and they have been sampled monthly in this study from February 1992 to April 2001. 
In contrast to previous studies, we do not find that Merton's model predicts spreads which are too small. On average, across our nine-year sample of between 20 and 78 bonds, the model and market spreads are of similar magnitude. At the same time, using cross-sections at three different dates, we confirm two of the systematic biases found in previous studies, namely that model spreads are "too small" (i) for bonds which are near to maturity and (ii) for companies with low leverage and volatility.

Another controversy on which we shed some light is whether structural models produce the right shape for the term-structure of credit spreads. In cross-section, our sample of medium-risk bonds consistently produces an upward-sloping termstructure. Models predict that it should be upward-sloping for relatively safe bonds and downward-sloping for risky bonds. The solution to this conundrum appears to be that the leverage of the companies changes over time, being higher when bonds are issued than when they mature. Allowing for this leverage effect leads to model termstructures of credit risk which are upward-sloping, as empirically observed. This result is consistent with the recent studies by Helwege and Turner (1999) and by He, $\mathrm{Hu}$ and Lang (2000), which consider pairs of bonds issued by the same company in order to eliminate leverage effects. It also reinforces the conclusion of CollinDufresne and Goldstein (2001) that it is important to take account of the expected trajectory of leverage when computing credit spreads.

Using time-series data, we are able to explain about one quarter of the deviation of market spreads from model spreads, based on movements in market volatility, the term-structure of interest rates and the discount on closed-end funds. We suggest that investors may not be fully rational in the way they adjust the credit spread in relation to these factors. The difficulty in attributing changes in spreads to economic variables has also been noted by Collin-Dufresne, Goldstein and Martin (2001), who conclude that credit spreads are driven by "local demand/supply shocks". We think that this evidence is consistent with changes in investor sentiment.

The paper is written as follows. In the second section we review previous work on credit spreads and describe the setting of the paper. In the third section we discuss the data to be used and the model. In the fourth section the results are given and 
discussed. The fifth, and final, section gives the conclusions and implications of this study.

\section{Review and Problem Setting}

As already stated, the literature on credit spreads is divided into structural models (using option-pricing, after Merton (1974)) and reduced-form models (e.g. Jarrow and Turnbull (1995), Duffie and Singleton (1999)). This paper is only concerned with structural models and their performance. ${ }^{1}$ For a very simple firm which comprises equity and one zero-coupon bond, the pay-off at maturity to the risky bond has the features of a risk-free bond less the value of a put option on the firm's value which is struck at the bond's face value $(\mathrm{X})$ - see Figure 1. If the company has other debt which is risk-free and ranks above the bond with face-value $\mathrm{B}$, then the bond payment at maturity has the profile of a bull spread and the risky bond is equal in value to a risk-free bond, less the value of a put option struck at $\mathrm{B}+\mathrm{X}-$ see Figure 2. It is then an elementary calculation to find the put-option value and so the value of the risky bond.

One basic feature of Merton's model is that the firm's value drifts upwards over time (at the risk-free rate in the risk-neutral world of option pricing) and so its leverage falls. This is illustrated in Figure 3, where the whole distribution of firm value eventually exceeds the exercise price of $(\mathrm{B}+\mathrm{X})$ and the bond becomes risk-free. The resulting profile for the term-structure of credit spreads generated by the model is downward-sloping (see Figure 4), because of the implicit fall in leverage of the firm over time.

Merton's model has been extended in many ways. For most companies it seems more realistic to assume that there is a target leverage ratio which they try to maintain by issuing or retiring debt. Schoebel (1999) and Collin-Dufresne and Goldstein (2001) assume constant leverage, which results in much larger spreads and a term structure in which spreads increase with maturity. Leland and Toft (1996) use a slightly different

\footnotetext{
${ }^{1}$ There are also some papers which try to combine elements of both types of model. For example, Cathcart and El-Jahel (1999) use a hazard rate together with a structural model and Wang and Hodges (2001) incorporate a moving average of changes in firm value into a reduced-form model.
} 
modification, which is to assume that default on a coupon date is avoided by issuing new equity. This "option to reduce leverage" also results in much larger spreads than in the basic Merton model.

A second modification is concerned with companies which have several issues of bonds. If the company fails to pay a coupon at any time, then all of the bonds default simultaneously. Longstaff and Schwartz (1995) assume that default occurs on all bonds when the firm's value reaches a particular barrier and they incorporate this feature into Merton's model. ${ }^{2}$ Longstaff and Schwartz (1995) also allow interest rates to be stochastic, following a procedure used in Black and Cox (1976).

Empirical studies of credit spreads using structural models are quite rare. They are complicated by the following features: (i) companies have more than one issue of debt; (ii) the debt is coupon-paying; (iii) there are call features and sinking funds; and (iv) the firm value must be known in order to find its volatility, yet at the same time the volatility affects the value of the debt and hence the firm value. In particular the need to exclude companies which do not have very simple capital structures has led to small samples of bonds being available for testing the models.

Jones, Mason and Roenfeld (1984) consider 27 firms with simple capital structures, monthly over 1978-81. Their main conclusions are that Merton's model generates spreads which are smaller than those observed in the market, particularly for lowgrade bonds. ${ }^{3}$ Ogden (1987) investigates 57 new bond issues over 1973-85. Model spreads are on average 104 basis points smaller than those observed in the market and the differences are related to the level and slope of the term-structure of interest rates. Eom, Helwege and Huang (2000) use a sample of 54 bonds (from 48 firms) in December 1997 and compare the pricing errors generated by the models of Merton (1974), Geske (1979), Longstaff and Schwartz (1995), and Leland and Toft (1996). Spreads from Merton's model are 10-15\% too small and the extension by Geske, which allows for serial dependence in coupon defaults, does not make much difference. The model of Longstaff and Schwartz generates spreads which are on

\footnotetext{
${ }^{2}$ Briys and de Varenne (1997) and Schoebel (1999) make further refinements which overcome the problem of payments to bondholders potentially exceeding the value of the firm.
} 
average of the right magnitude, but with mean-absolute-percentage errors just as large as for Merton's model. Leland and Toft's approach generates spreads which are even larger and subject to greater errors (between market and model prices). The upshot of the study is that the simple structural models (Merton and Geske) forecast spreads which are smaller than market spreads, particularly for companies which have low leverage and low volatility, but the more complicated structural models which produce larger spreads (Longstaff/Schwartz and Leland/Toft) also produce large errors. Another finding is that whether a model allows for stochastic interest rates or not does not make much difference.

Some other empirical papers dealing with the term-structure of spreads are also relevant to our study. Practitioners claim that the term-structure should be upwardsloping, but structural models (Merton (1974), Longstaff and Schwartz (1995)) and reduced-form models (Jarrow, Lando and Turnbull (1997)) predict that it will slope upward for high-grade bonds and downward for low-grade bonds. The intuition is that low-grade bonds have a chance to upgrade, hence their declining spread, and the converse for high-grade bonds. Helwege and Turner (1999), using pairs of bonds from the same company, confirm that $\mathrm{B}$ and $\mathrm{BB}$ rated bonds do show an upward slope (contrary to the earlier cross-sectional studies of Sarig and Warga (1989) and Fons (1987)). Using a similar approach, He, Hu and Lang (2000) confirm the upward slope for high-grade ( $\mathrm{B}$ or better) bonds and a downward slope for low-grade (CC or worse) bonds.

Other real-world features which may increase spreads but do not affect the shape of the term-structure are taxation and transactions costs. According to Elton, Gruber, Agrawal and Mann (2000) the taxation of corporate bonds in the US is higher than of government bonds and this should "fatten" the spread. Similarly, Ericsson and Renault (2001) find that there is a liquidity premium in the observed credit spread which increases its size.

The implications for the current study of this brief review are as follows: (i) structural models tend to predict smaller spreads than those observed in practice, except if

\footnotetext{
${ }^{3}$ They report in terms of prices rather than spreads, finding that on average investment-grade bonds are
} 
leverage is allowed to change over time; (ii) the models forecast particularly small spreads for bonds which are near to maturity and for companies with low volatility and low leverage; (iii) there is some evidence that the models predict the correct shape of the term-structure of spreads - upward for high-grade bonds and downward for low-grade bonds; (iv) most empirical studies have had to adjust for coupons and have been based on small samples of companies which have simple capital structures. This study does not suffer the limitations in (iv) and it aims to provide answers to questions (i) to (iii).

\section{$\underline{\text { 3. Data and Model }}$}

The sample consists of zero-coupon bonds issued by closed-end funds in the UK. A closed-end fund is a quoted company which holds a portfolio of investments on behalf of its shareholders. Split-capital closed-end funds, which have existed since 1965 in the UK, are financed approximately $50 \%$ with debt and $50 \%$ with equity (see Gemmill, 2001, for more details). On average, one third of the debt is bank loan and the remaining two-thirds is zero-coupon bonds, known as "zero-dividend preference shares" (ZDPs). These bonds rank immediately after the bank debt and before any other classes of share. Unlike most closed-end funds, these split-capital funds have a fixed maturity which coincides with the maturity of the bonds.

The capital structure of a typical split-capital closed-end fund is illustrated by the JP Morgan Fleming Income and Capital Investment Trust. This was launched in February 2002 and winds-up after six years. It comprised at issue:

- Bank loan

- $20 \%$ of capital

- Zero-dividend preference shares (zero-coupon bonds)

- $36 \%$ of capital

- Ordinary shares

○ $44 \%$ of capital

worth $0.5 \%$ less than predicted and low-grade bonds are worth $10.5 \%$ less than predicted. 
The bonds were issued at a price of 100 pence and promise to pay 154.15 pence on $29^{\text {th }}$ February 2008 , so that the prospective yield is $7.5 \%$ per annum.

Our sample comprises between 20 and 78 bonds, observed monthly over the period February 1992 to April 2001 (see Figure 5). ${ }^{4}$ In total there are 4594 "fund month" observations, slightly less than the full population because records are missing for six particular months from the 111-month series.

Given a value $\mathrm{B}$ for the bank loan and a face-value $\mathrm{X}$ for the bonds, the value of the bonds ( $\mathrm{Z}$ ) may be equated to buying a call option on the portfolio at exercise price $\mathrm{B}$ and selling a call option on the portfolio at exercise price $(B+X)$. We have,

$\mathrm{Z}=\mathrm{c}(\mathrm{B})-\mathrm{c}(\mathrm{B}+\mathrm{X})$

where $\mathrm{c}($ ) denotes a call option.

The prospective pay-off to this bull spread at maturity has already been illustrated in Figure 2. It is convenient, and relatively plausible, to assume that the bank loan (B) is risk-free. The reason is that the banks impose severe covenants, requiring assets to exceed debt by at least 1.75 to 1.85 times. $^{5}$ Under this assumption we may write,

$\mathrm{c}(\mathrm{B})=\mathrm{V}-\mathrm{PV}(\mathrm{B})$

where V denotes firm value and PV denotes the present-value operator. Combining (1) and (2) leads to,

$\mathrm{Z}=\mathrm{V}-\mathrm{PV}(\mathrm{B})-\mathrm{c}(\mathrm{B}+\mathrm{X})$

From put/call parity we have,

$\mathrm{V}-\mathrm{c}(\mathrm{B}+\mathrm{X})=\mathrm{PV}(\mathrm{B}+\mathrm{X})-\mathrm{p}(\mathrm{B}+\mathrm{X})$

where $p($ ) denotes a put option. Rearranging (3) with (4) leads to,

\footnotetext{
${ }^{4}$ The data come from the Cazenove Monthly Review of Investment Trusts.
} 
$\mathrm{Z}=\mathrm{PV}(\mathrm{X})-\mathrm{p}(\mathrm{B}+\mathrm{X})$

which states that a zero-dividend preference share is equal in value to the present value of a risk-free bond less the value of a put option for which the exercise price is equal to the sum of the payments due at maturity on the bank loan and the bond.

The put is European and, assuming constant interest rates, can be valued with the Black and Scholes equation. For the closed-end funds in this study, the value of the company (V) is taken to be the market value of the portfolio held (i.e. its gross asset value) and the volatility may be estimated from the time-series of that value. In the study the risk-free rate is taken from an estimated term-structure of rates for the relevant day. ${ }^{6}$ An adjustment for the dividend yield is made, based on the dividends paid-out on each fund's portfolio.

\section{Results}

The first feature which we examine is the term-structure of credit spreads. Figure 6 plots the observed relationship for the sample of bonds in June 2000. There is a discernible tendency for the spread to rise with maturity, as shown by the fitted curve. As already illustrated in Figure 4, Merton's model indicates that the spread should fall with maturity (based on a representative volatility of $15 \%$ and bonds which are at-themoney or in-the-money. ${ }^{7}$ The contrast between the market and the model is great, but may be explained by considering the expected change in moneyness over time.

Figure 4 assumes that moneyness is constant, so a bond which is issued at-the-money remains so until maturity. In reality zero-dividend prefence shares are issued at-themoney and may be expected to move into-the-money over time, as the value of the portfolio drifts upwards. Effectively the leverage of a new issue is higher than that of a fund which is close to maturity. Figure 7 plots the term structure which the model would generate if a fund's value drifted upwards at a rate of $7 \%$ per annum, implying that bonds which start $34 \%$ out-of-the-money will finish after ten years $30 \%$ in-the-

\footnotetext{
${ }^{5}$ This has similarity to a CDO structure, see e.g. Duffie and Garleanu (2001).

${ }^{6} \mathrm{We}$ are grateful to the Bank of England for providing these data.
} 
money. The changing moneyness and leverage generate an upward-sloping term structure, which is consistent with the upward slope in our sample for June 2000 and which also arises in other months. Merton's model is consistent with the upwardsloping term-structure of credit spreads which we observe, provided that we assume that leverage falls systematically as the bonds move closer to maturity.

We turn now to the results for average spread across all bonds in each of the months. Table 1 and Figure 8 summarise the monthly differences between market yields and model yields for the period February 1992 to April 2001. In the early part of the sample, market yields are significantly less than model yields, but then for a long period between 1994 and 1999 the two yields are rather similar. After March 2000, for the last year of the sample, the market yields significantly exceed model yields. These results are different from those in previous studies, which always find market yields to exceed model yields (e.g. Eom et al, 2000). Our study therefore appears to support the Merton model much more strongly than previous empirical studies which have all been based on US data and on coupon-paying bonds.

An explanation of the contrasting UK and US results could be due to differences in taxation of corporate bonds in the two countries. Elton et al (2001) attribute about one third of the observed US spread to state and local taxes, which apply to corporate bonds but not to treasuries. It would therefore not be surprising if model spreads appeared to be smaller than market spreads in the US, although surprisingly only Elton et al have discussed tax as a factor in this regard. For the UK, not only is there no extra tax levied on corporate bonds, but also the particular bonds of this study benefit from being taxed as capital gains rather than as income. We would therefore expect the market spreads in the UK to be somewhat smaller than for equivalent bonds in the US, which could (at least partially) explain the closer fit with Merton's model. ${ }^{8}$

The next question is how well the model captures cross-sectional variation in spreads. To do this, the samples in June 1992, June 1996 and June 2000 are used, as they

\footnotetext{
${ }^{7}$ By in-the-money is meant with assets for which the present value exceeds the final payment on the bond.

${ }^{8}$ The tax benefit is discussed in Gemmill, 2001.
} 
represent periods in which the average market spread (relative to the model spread) is respectively too small, about right, and too large. Figures 9,10 and 11 plot model yields against market yields for these dates. There is a convincingly positive relationship between model and market yields in each period, particularly so in June 1996 when the averages for the two are of very similar magnitude.

In specifying a regression to explain the difference between market spreads and model spreads, several factors may come into play: (i) a more liquid bond may have a smaller market spread, and this is proxied by the total value of the bonds in a given issue; (ii) previous sudies show that more risky (leveraged) bonds have extra-large spreads and this possibility is proxied by a moneyness variable (where high moneyness implies low leverage and low risk of default) ${ }^{9}$; (iii) the model may be biased in relation to the term-structure of credit spreads and this may be tested by including a variable for time to maturity. Because the distributions of the independent variables are significantly non-normal, they are specified in log form, i.e.

$($ market spread - model spread $)=a+b \log ($ size of issue $)+c \log ($ forward moneyness $)+\mathrm{d} \log ($ years to maturity $)+$ error term

The results of the estimated regressions are given in Table 2. The first result is that there is a consistent impact of moneyness, significant at the $1 \%$ level in two of the years and at the 5\% level in the third year. This indicates that when there is low leverage the model tends to underestimate the market spread, which is precisely the result found in the US literature. The model attributes "too small a spread" to safe companies. The second result is a negative impact of years to maturity on the market spread over model spread (significant at the 5\% level in all three years), which indicates that the model attributes "too small a spread" to bonds which are near to maturity. ${ }^{10}$ Again, this result is consistent with the US literature. The third result is that size of issue, a proxy for liquidity, has no significant impact in any year and therefore appears to be unimportant. To summarise, these cross-section regressions suggest that the same biases exist in our UK sample of zero-coupon bonds as exist for

\footnotetext{
${ }^{9}$ We use forward moneyness, rather than current moneyness. This is a more appropriate measure of leverage and it reduces collinearity with the time-to-maturity variable.
} 
US coupon-paying bonds - i.e. model spreads are too small for leveraged companies and for bonds which are near to maturity.

Next we consider the time-series behaviour of the market spread minus model spread, using the monthly average data already plotted in Figure 8. We hypothesise that the following variables may have an influence: (i) the market volatility over the last 20 months, because investors may respond to this in a way which is different from that implicit in the model -- in other words, investors may not be completely rational; (ii) the premium on closed-end funds, because a larger premium may result in an upgrading of the bonds -- this would also not be rational, since the bonds are repaid from the gross asset value and not from the fund's equity, so the premium is irrelevant; (iii) 10-year interest rates and (iv) the spread of 10-year rates over oneyear rates, because movements in the term-structure of interest rates may affect market spreads relative to model spreads in some complicated way (as suggested by Ogden, 1987).

Single-variable plots of model "errors" (i.e. market spreads minus model spreads) against the premium on closed-end funds (Figure 12) and against market volatility (Figure 13) suggest that there may be quite strong effects of these variables. The regression is estimated in first-differences, as that is required for stationarity of the variables. A correction is made for heteroscedasticity by weighting each month's data by the estimated cross-sectional variance in that month (which should be a highlyappropriate procedure for accommodating the changing variance). The form of the regression is:

$\Delta($ market spread - model spread $)=\mathrm{a}+\mathrm{b} \Delta$ (market volatility $)+\mathrm{c} \Delta($ closed-end-fund premium $)+\mathrm{d} \Delta(10$-year interest rate $)+\mathrm{e} \Delta(10$-year interest rate minus 1 -year interest rate) + error

The coefficients from the regression, all of which are significant at the $5 \%$ level or better, are given in Table 3. Some caution is needed in interpreting these results. The significance of the coefficients may either indicate that the model is wrong, or it may

\footnotetext{
${ }^{10}$ The alternative interpretation, that distant bonds have excessively large model spreads, is rejected by
} 
indicate that the market is inefficient (and subject to movements based on investor sentiment). Small investors are the main holders of these closed-end-fund bonds and changes in their "sentiment" have been shown to have an impact on the prices of closed-end funds (Gemmill and Thomas, 2002). We will therefore take a behavioural approach to interpreting the results in this study, i.e. an interpretation based on the likelihood that there is changing investor sentiment. This interpretation is also supported by the recent study of Collin-Dufresne, Goldstein and Martin (2001) which finds that credit spreads are mainly influenced by "local supply/demand shocks" rather than well-defined fundamental factors.

The first result is that higher market volatility reduces the market spread relative to the model spread. In other words, in risky periods the market prices of the bonds are bid up relative to model prices. One reason for this might be due to investors seeking "safe havens" in unsettled periods (to an irrational degree). The result suggests that the model underestimates (or market overestimates) spreads not just for low-risk bonds, as found in cross section, but for all bonds in low-risk periods. The second result is that when the closed-end fund premium increases (discount falls), the market spread widens relative to the model spread. The interpretation may be as follows. When the stockmarket rises there is a tendency for the closed-end-fund premium to rise (as private investors increase their holdings of closed-end funds, see Gemmill and Thomas, 2002). A shift in investment towards closed-end-fund equity might simultaneously be associated with a move out of closed-end-fund bonds, leading to wider spreads. The third result is that market spreads increase relative to model spreads when the term-structure steepens and interest-rates fall, which confirms the result from the study by Ogden (1987) on US bonds. Such a shift in term structure is associated with a change from boom to recession in the economy and it suggests that investors downgrade bonds (increasing market spreads) more severely than suggested by the model at such a time. Once again a shift in sentiment would be consistent with this result.

a tabulation of the data. 


\section{Conclusions and Final Thoughts}

This study applies Merton's model to a sample of zero-coupon bonds in the UK. These particular bonds are especially appropriate for a test of the model, because the issuing companies are closed-end funds which have very simple capital structures and transparent values. To the best of our knowledge, there has been no previous empirical study of Merton's model based upon zero-coupon bonds, because it is difficult to find a sample. ${ }^{11}$

Our results reject one previous finding but confirm others. The previous finding which we reject is that the model generates spreads which are less than those in the market. We find that market spreads are on average equal to model spreads, for the 20 to 78 bonds which we observe monthly from February 1992 to April 2001. In the first year of the sample, when these zero-coupon bonds are an innovation, the market spread is well below the model spread. For the last year of the sample, when the stockmarket is volatile and has made a downward shift, the market spread exceeds the model spread. For the seven years in between, the market and model spreads are quite close together for the average bond.

The findings which we confirm empirically (from cross-section analysis at three separate dates) are twofold. First, the model spreads are small relative to market spreads for bonds which are near to maturity. Second, model spreads are also "too small" for bonds which have low leverage.

Another aspect on which we shed some light is whether the term-structure of credit spreads is upward or downward sloping. In cross-section, our sample of bonds shows an upward-sloping profile for the term-structure of credit spreads. This is perfectly consistent with the profile generated by Merton's model, as long as it is assumed that there will be a drift in leverage over time. In particular, for our sample of bonds which are issued by closed-end funds, the leverage may be expected to fall over time, causing the spread to fall on each bond as it approaches maturity. This observation 
supports the argument of Collin-Dufresne and Goldstein (2001), that specifying the appropriate target for leverage has a large influence on model spreads.

Finally, with respect to conclusions, we find that there are systematic movements over time in the the difference between market spreads and model spreads. This difference is sensitive to market volatility, to the premium on closed-end funds and to the shape of the term-structure of interest rates. The zero-coupon bonds of this study are predominantly held by small investors and the changes in spreads may possibly be interpreted as responses to changing investor sentiment. While our interpretation is open to the usual caveat, namely that what we attribute to market inefficiency could also be attributed to use of an inappropriate model, it is consistent with the study by Collin-Dufresne, Goldstein and Martin (2001), which finds that local demand/supply shocks rather than more fundamental factors are the main influence on changes in US credit spreads.

In relation to final thoughts, the large question which remains unanswered is why Merton's model has moneyness and time-to-maturity biases? The market attributes much larger spreads than the model to bonds which are close to maturity and apparently safe. Ericsson and Renault (2001) find that liquidity might account for a 70 basis-point spread, but our cross-section regressions find no relationship between liquidity (proxied by size of issue) and spread. Another possibility is that the distribution of firm value exhibits kurtosis, so the put values in Merton's model are underestimated and the model yields too low. The kurtosis has its largest impact on model values when a bond is both near to maturity and relatively safe. Further research along these lines is required.

\footnotetext{
${ }^{11}$ Ericsson and Renault (2001) use a sample of US corporate zero-coupon bonds to test indirectly for the presence of liquidity risk.
} 


\section{References}

Black, Fischer and Myron Scholes. "The Pricing Of Options And Corporate Liabilities," Journal of Political Economy, 1973, v81(3), 637-654.

Black, Fischer and John C. Cox. "Valuing Corporate Securities: Some Effects Of Bond Indenture Provisions," Journal of Finance, 1976, v31(2), 351-367.

Briys, Eric and Francois De Varenne. "Valuing Risky Fixed Rate Debt: An Extension," Journal of Financial and Quantitative Analysis, 1997, v32(2,Jun), 239248.

Cathcart, Lara and Lina El-Jahel. "Pricing Defaultable Bonds: A Middle-Way Approach Between Structural and Reduced-Form Models," working paper, Management School, Imperial College, February 1999.

Collin-Dufresne, Pierre and Robert Goldstein. "Do Credit Spreads Reflect Stationary Leverage Ratios?," Journal of Finance, 2001, v56, 1928-1957.

Collin-Dufresne, Pierre, Robert Goldstein and J.Spencer Martin. “The Determinants of Credit Spread Changes," Journal of Finance, 2001, v56(6), 2177-2208.

Duffie, Darrell and and Nicholas Garleanu. " Risk and Valuation of CDOs," Financial Analysts Journal, 2001, Jan/Feb, 41-59.

Duffie, D. and K. J. Singleton. "Modeling Term Structures Of Defaultable Bonds," Review of Financial Studies, 1999, v12(Spec), 687-720.

Elton, Edward, Martin Gruber, Deepak Agrawal and Christopher Mann. "Explaining the Rate Spread on Corporate Bonds," Journal of Finance, 2001,v56(1),

Eom, Young Ho, Jean Helwege, and Jing-Zhi Huang. "Structural Models of Corporate Bond Pricing: An Empirical Analysis," working paper no. 2000-16, Pennsylvania State University, October 2000.

Ericsson, Jan and Olivier Renault. "Liquidity and Credit Risk," working paper, Financial Market Group, London School of Economics, August 2001.

Fons, Jerome S. "The Default Premium And Corporate Bond Experience," Journal of Finance, 1987, v42(1), 81-97.

Gemmill, Gordon. "Financial Engineering and Firm Value: A Study of Split-Capital Closed-End Funds," working paper, City University Business School, October 2001.

Gemmill, Gordon and Dylan C. Thomas. "Noise Trading, Costly Arbitrage and Asset Prices: Evidence from Closed-End Funds", forthcoming, Journal of Finance, 2002.

Geske, Robert. "The Valuation Of Compound Options," Journal of Financial Economics, 1979, v7(1), 63-82. 
He, Jia, Wenwui Hu and Larry Lang. "Credit Spread Curves and Credit Ratings," working paper, Chinese University of Hong Kong, 2000.

Helwege, Jean and Christopher Turner. "The Slope of the Credit Yield Curve for Speculative-Grade Issuers," Journal of Finance, 1999, v54(5), 1869-1884.

Jarrow, Robert A. and Stuart M. Turnbull. "Pricing Derivatives On Financial Securities Subject To Credit Risk," Journal of Finance, 1995, v50(1), 53-85.

Jarrow, Robert, David Lando, and Stuart Turnbull. "A Markov Model For The Term Structure Of Credit Risk Spreads," Review of Financial Studies, 1997, v10(2,Summer), 481-523.

Jones, E. Philip, Scott P. Mason and Eric Rosenfeld. "Contingent Claims Analysis Of Corporate Capital Structures: An Empirical Investigation," Journal of Finance, 1984, v39(3), 611-625.

Kim, In Joon, Krishna Ramaswamy and Suresh Sundaresan. "Does Default Risk In Coupons Affect The Valuation Of Corporate Bonds? A Contingent Claims Model," Financial Management, 1993, v22(3), 117-131.

Leland, Hayne E. and Klaus Bjerre Toft. "Optimal Capital Structure, Endogenous Bankruptcy, And The Term Structure Of Credit Spreads," Journal of Finance, 1996, v51(3,Jul), 987-1019.

Longstaff, Francis A. and Eduardo S. Schwartz. "A Simple Approach To Valuing Risky Fixed And Floating Rate Debt," Journal of Finance, 1995, v50(3), 789-819.

Merton, Robert C. "On The Pricing Of Corporate Debt: The Risk Structure Of Interest Rates," Journal of Finance, 1974, v29(2), 449-470.

Ogden, Joseph P. "Determinants Of The Ratings And Yields On Corporate Bonds: Tests Of The Contingent Claims Model," Journal of Financial Research, 1987, v10(4), 329-340.

Jan Ericsson and Olivier Renault. "Liquidity and Credit Risk," working paper, London School of Economics, 2001.

Sarig, Oded and Arthur Warga. "Some Empirical Estimates Of The Risk Structure Of Interest Rates," Journal of Finance, 1989, v44(5), 1351-1360.

Schoebel, Rainer. "A Note of hte Valuation of Risky Corporate Bonds," OR Spektrum, 1999, v21 (1-2),

Wang, Mark and Stewart Hodges. "A Reduced-Form Model Incorporating Fundamental Variables," working paper, University of Warwick, April 2001. 
$\underline{\text { Table } 1} \underline{\text { Summary of the Monthly Deviation of Market Spreads from Model Spreads }}$

\begin{tabular}{|c|c|c|c|c|c|}
\hline period & $\begin{array}{l}\text { average of } \\
\text { monthly } \\
\text { deviations } \\
\text { (percentage } \\
\text { points of } \\
\text { rate) }\end{array}$ & $\begin{array}{l}\text { standard } \\
\text { error }\end{array}$ & t-value & $\begin{array}{l}\text { maximum } \\
\text { month } \\
\text { deviation }\end{array}$ & $\begin{array}{l}\text { minimum } \\
\text { month } \\
\text { deviation }\end{array}$ \\
\hline $2 / 92$ to $1 / 94$ & -1.4839 & 0.2401 & $6.180 * * *$ & 0.9033 & -3.1534 \\
\hline $2 / 94$ to $1 / 96$ & 0.0512 & 0.0946 & 0.541 & 1.0982 & -0.5436 \\
\hline $2 / 96$ to $1 / 98$ & 0.4311 & 0.0583 & $7.393 * * *$ & 0.9061 & -0.1360 \\
\hline $2 / 98$ to $1 / 00$ & 0.3748 & 0.0843 & $4.445 * * *$ & 1.3824 & -0.2183 \\
\hline $2 / 00$ to $4 / 01$ & 1.4533 & 0.1167 & $12.456 * * *$ & 2.0343 & 0.2869 \\
\hline $\begin{array}{l}\text { whole } \\
\text { sample }\end{array}$ & 0.0651 & 0.1094 & 0.596 & 2.0344 & -3.1534 \\
\hline
\end{tabular}

$*, * *, * * *$ indicate significance at $10 \%, 5 \%$ and $1 \%$ levels

$\underline{\text { Table } 2}$ Cross-Section Regressions to Explain (market spread - model spread)

\begin{tabular}{|c|c|c|c|c|c|c|}
\hline $\begin{array}{l}\text { sample } \\
\text { date }\end{array}$ & intercept & $\begin{array}{l}\text { log issue value } \\
\text { (liquidity) }\end{array}$ & $\begin{array}{l}\text { log forward } \\
\text { moneyness } \\
\text { (low leverage) }\end{array}$ & $\begin{array}{l}\text { log years } \\
\text { (maturity) }\end{array}$ & $\mathrm{R}^{2}$ & $\mathrm{~N}$ \\
\hline $\begin{array}{l}\text { June } \\
1992\end{array}$ & $\begin{array}{l}-4.9222 \\
(1.866)^{*}\end{array}$ & $\begin{array}{l}0.1911 \\
(1.467)\end{array}$ & $\begin{array}{l}3.1284 \\
(9.662)^{* * *}\end{array}$ & $\begin{array}{l}-0.7563 \\
(2.181)^{* *}\end{array}$ & 0.79 & 24 \\
\hline $\begin{array}{l}\text { June } \\
1996\end{array}$ & $\begin{array}{l}-2.5727 \\
(1.412)\end{array}$ & $\begin{array}{l}0.1681 \\
(1.669)\end{array}$ & $\begin{array}{l}0.7306 \\
(2.234) * *\end{array}$ & $\begin{array}{l}-0.2927 \\
(2.234)^{* *}\end{array}$ & 0.30 & 41 \\
\hline $\begin{array}{l}\text { June } \\
2000\end{array}$ & $\begin{array}{l}-1.9186 \\
(0.841)\end{array}$ & $\begin{array}{l}0.1783 \\
(1.458)\end{array}$ & $\begin{array}{l}1.1955 \\
(3.426)^{* * *}\end{array}$ & $\begin{array}{l}-0.3871 \\
(2.102)^{* *}\end{array}$ & 0.33 & 68 \\
\hline
\end{tabular}

Notes: numbers in brackets are White heteroscedasticity-corrected $\mathrm{t}$ values $*, * *, * * *$ indicate significance at $10 \%, 5 \%$ and $1 \%$ levels one outlier removed in June 1996 sample one outlier removed in June 2000 sample 
$\underline{\text { Table } 3}$ Time-Series Regression to Explain $\Delta$ (market spread - model spread)

\begin{tabular}{|l|l|l|l|l|}
\hline intercept & $\begin{array}{l}\Delta \text { market } \\
\text { volatility }\end{array}$ & $\begin{array}{l}\Delta \text { closed-end- } \\
\text { fund premium }\end{array}$ & $\begin{array}{l}\Delta 10 \text {-year risk- } \\
\text { free rate }\end{array}$ & $\begin{array}{l}\Delta 10 \text {-year } \\
\text { minus 1-year } \\
\text { risk-free rate }\end{array}$ \\
\hline-0.0261 & -0.0979 & 0.0638 & -0.5067 & 0.3611 \\
$(0.692)$ & $(3.091)^{* * *}$ & $(2.019)^{* *}$ & $(3.939)^{* * * *}$ & $(3.552)^{* * *}$ \\
\hline
\end{tabular}

$\mathrm{R}^{2}$ weighted $=0.24$, unweighted $=0.16$

$\mathrm{N}=98$ (after losing 12 observations due to differencing, with gaps)

DW $($ weighted $)=2.09$ 
Figure 1: Pay-Out to Risky Bond

bond pay-out

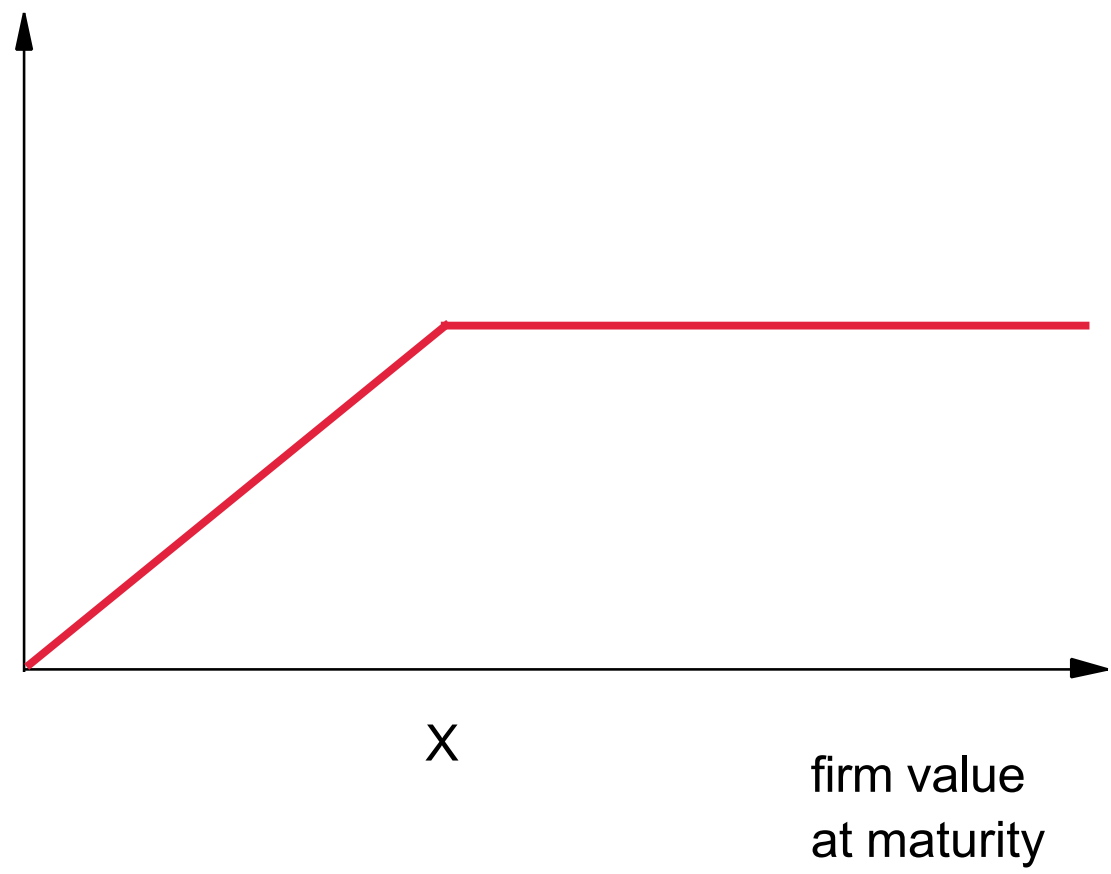

Figure 2: Pay-Out to Risky Bond when prior risk-free debt exists

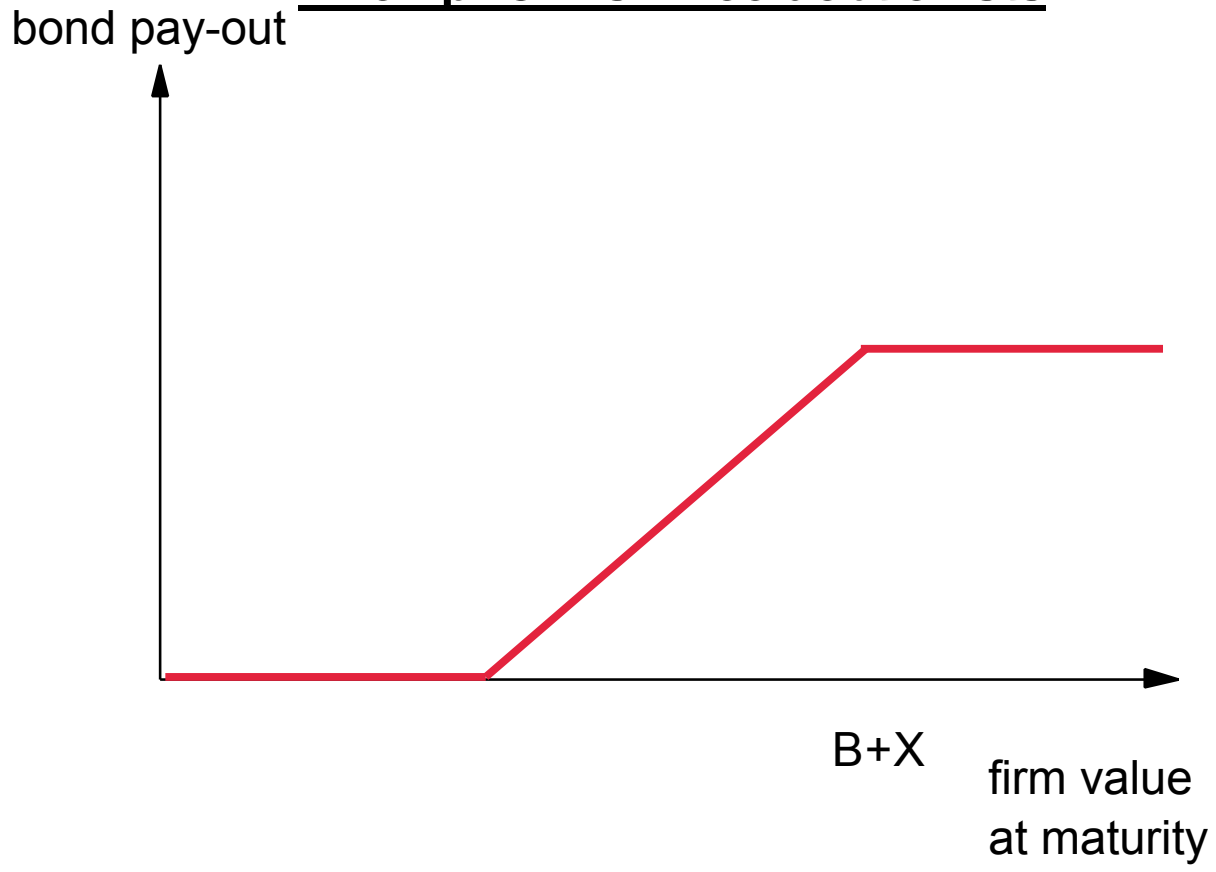


Figure 3 Drift in Firm Value Relative to Exercise Price

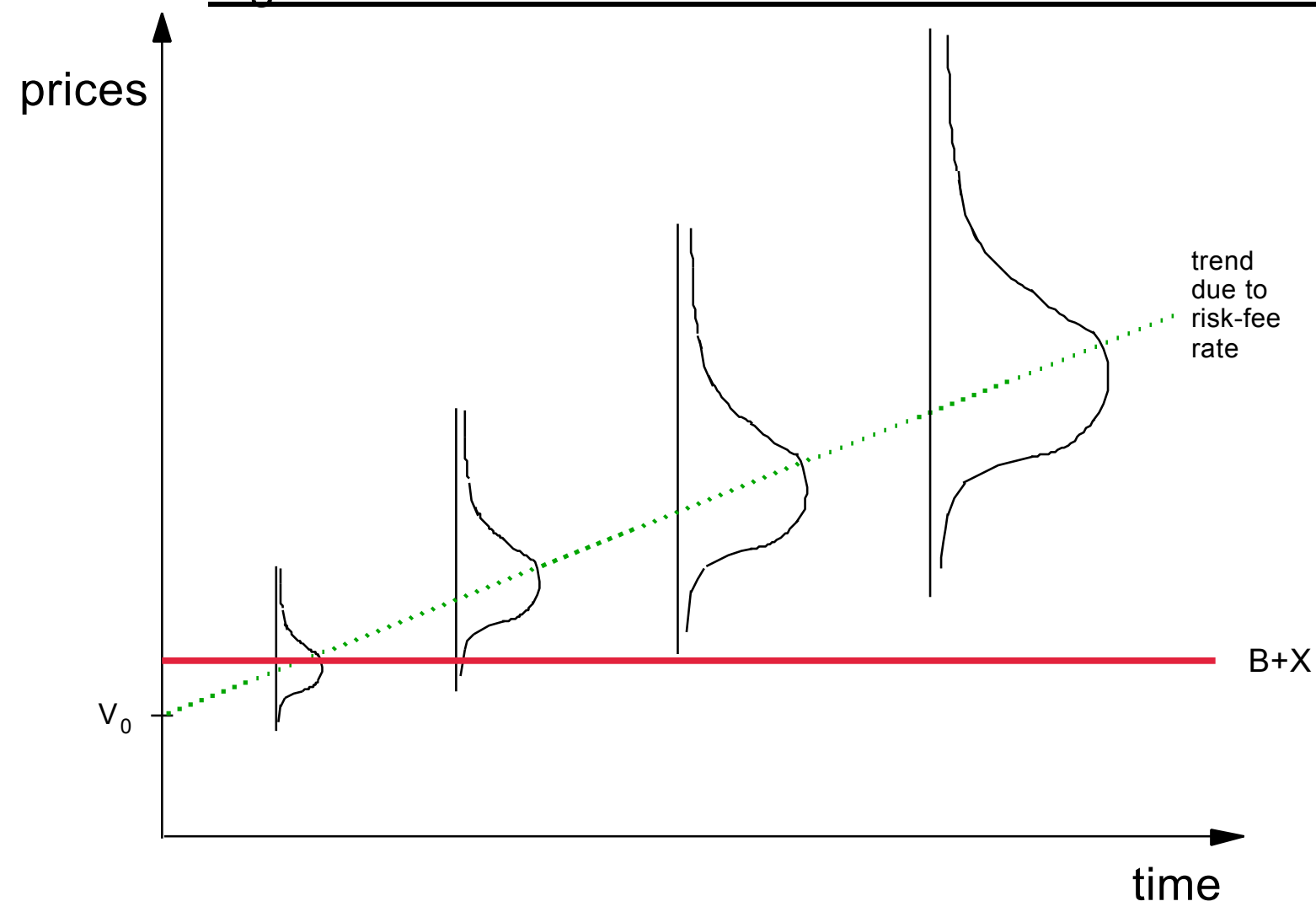

Figure 4: Credit Spreads on Zero Bonds (Merton)

(based on constant moneyness)

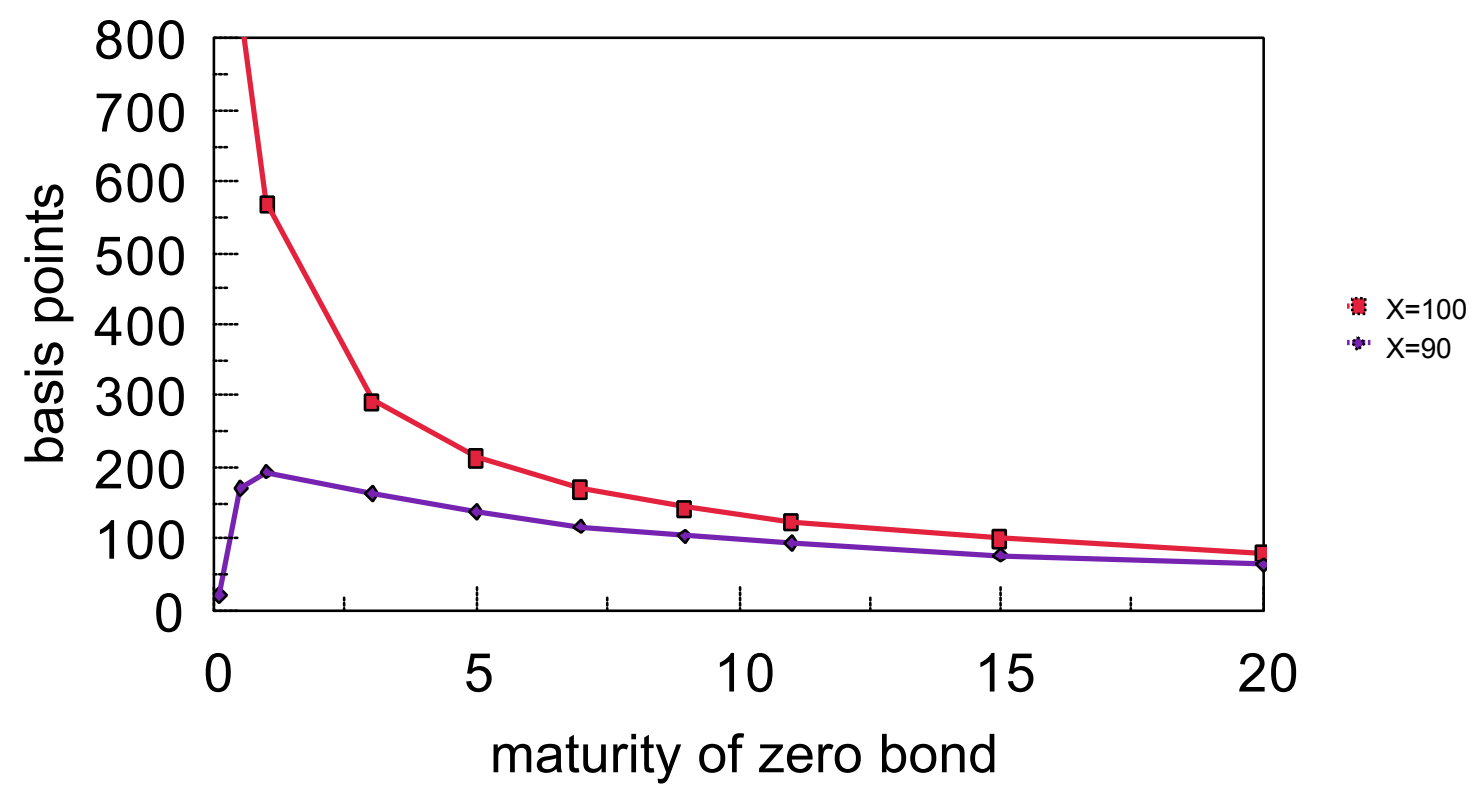

$s=100$, sigma $=0.15$, rann $=0.05$, divyield $=0.03$ 
Figure 5: Sample Size in each Month

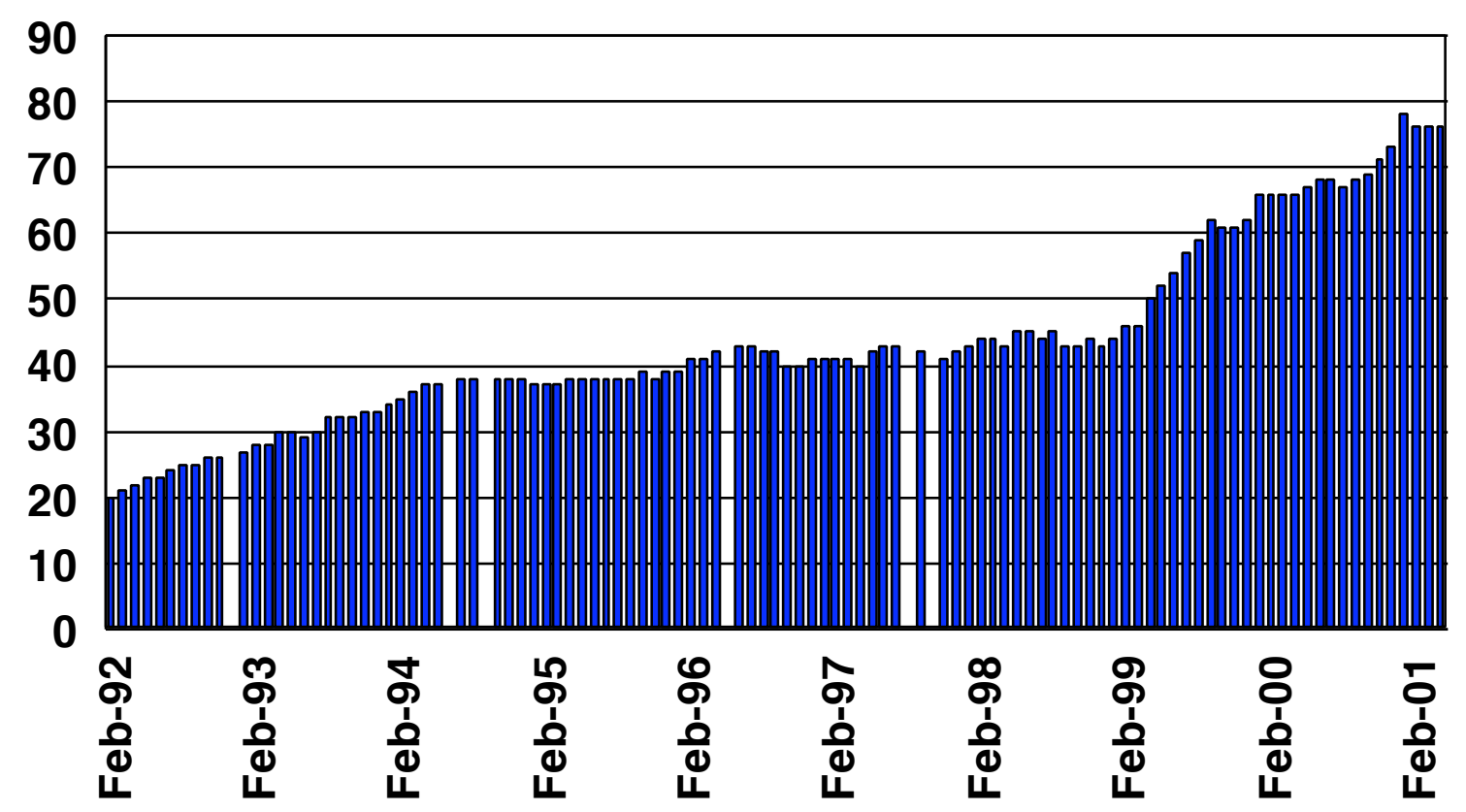

Figure 6: Spread over Spot Rate (June 2000)

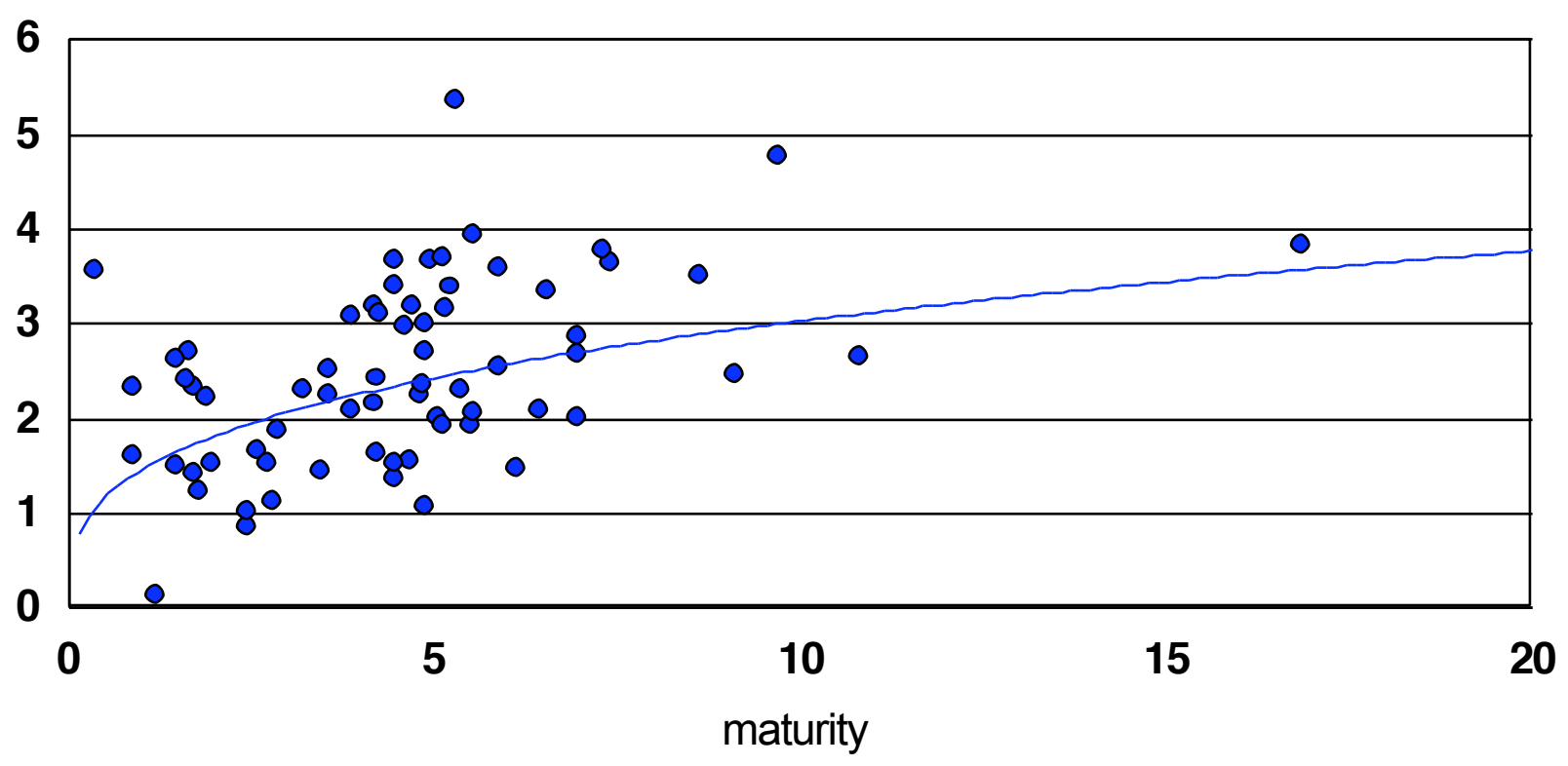


Figure 7: Merton's Model Credit Spreads with Share Drift (based on changing moneyness)

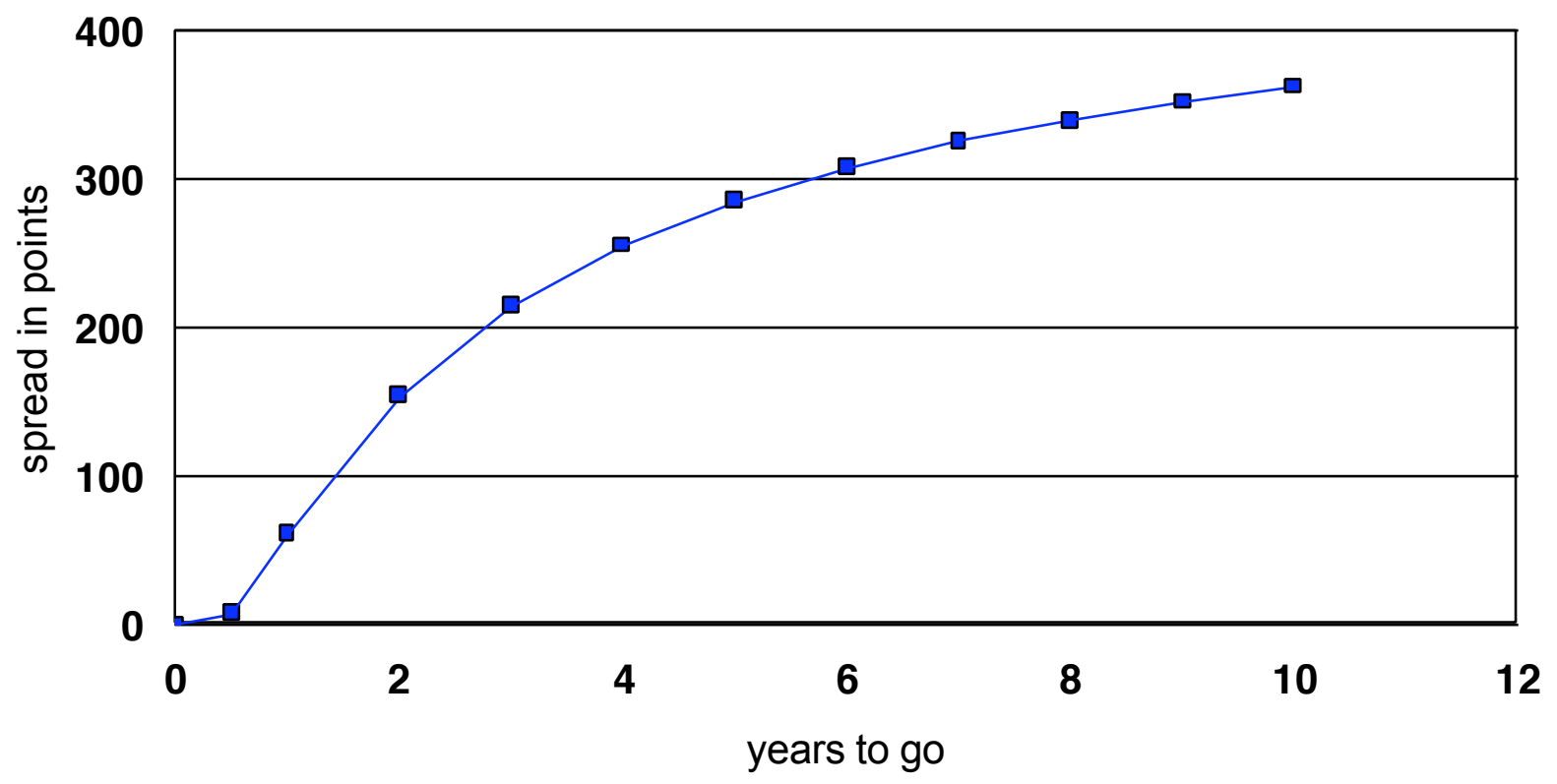

Note: drift of $7 \%: V / X=66.0 \%$ at 10 years, $130 \%$ at 0 years, sigma $=15 \%$

Figure 8: Market Spread Minus Model Spread (with $95 \%$ confidence range)

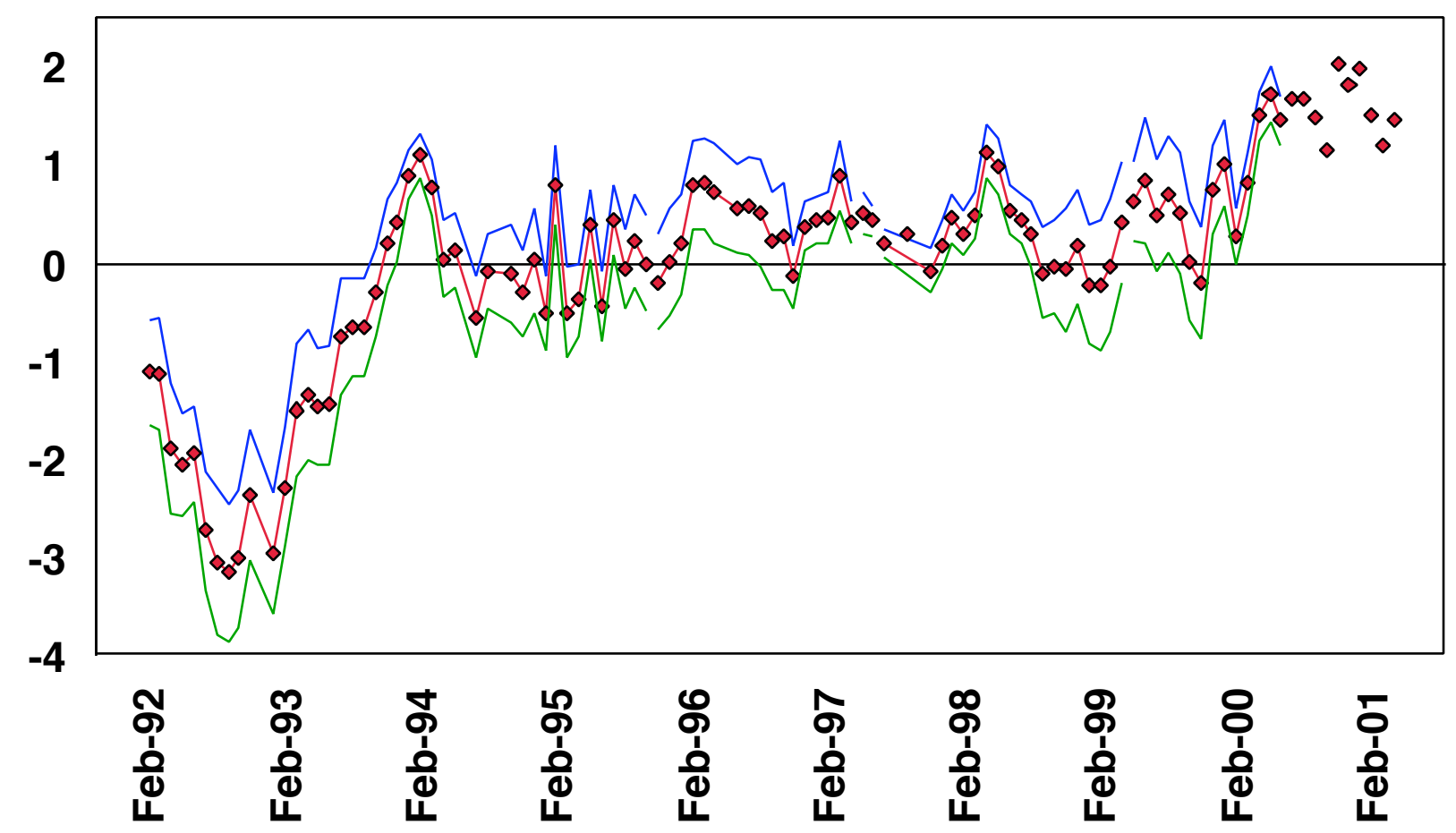


Figure 9: Model Yield v. Market Yield in June 1992

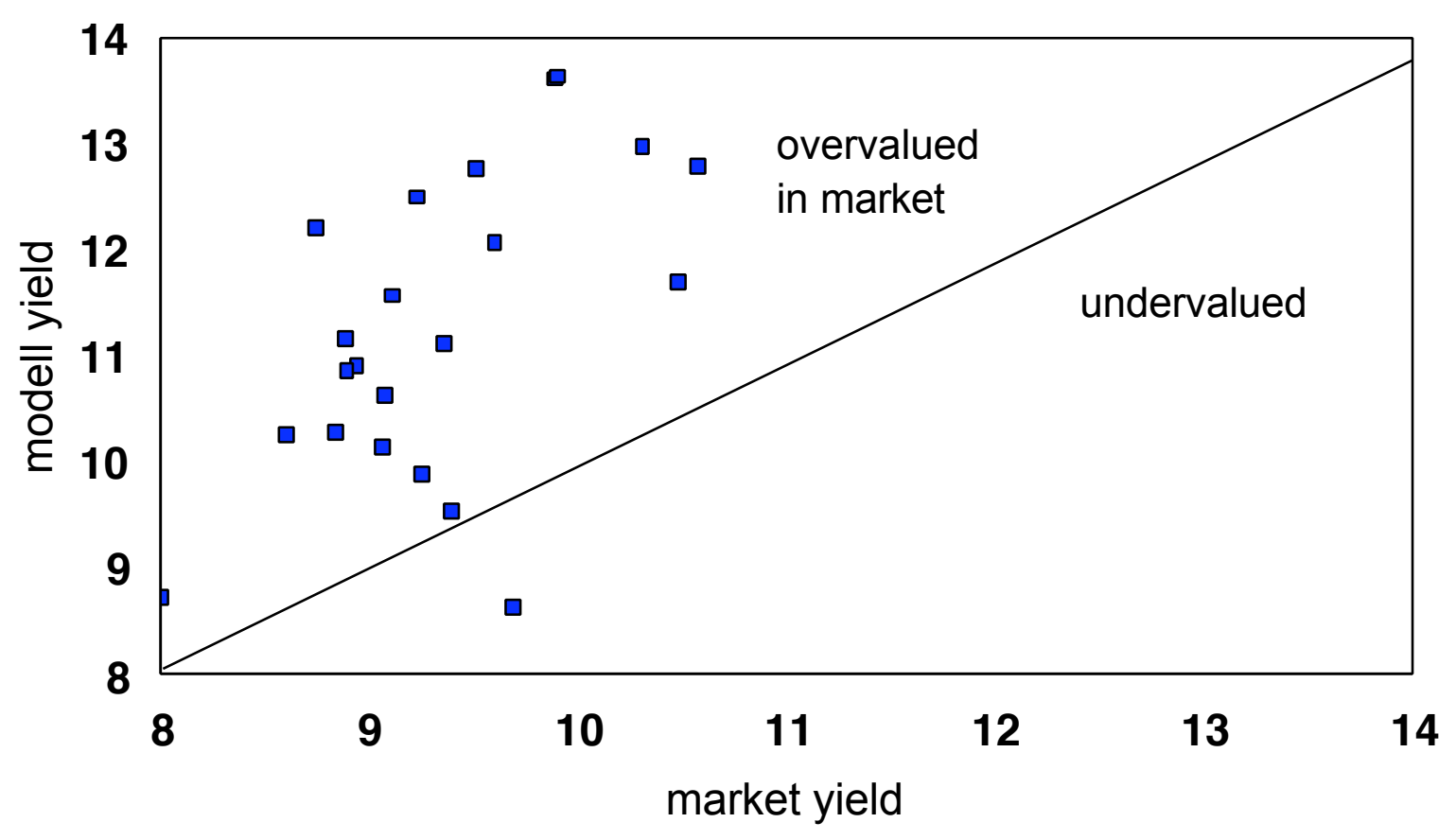

Figure 10: Model Yield v. Market Yield in June 1996

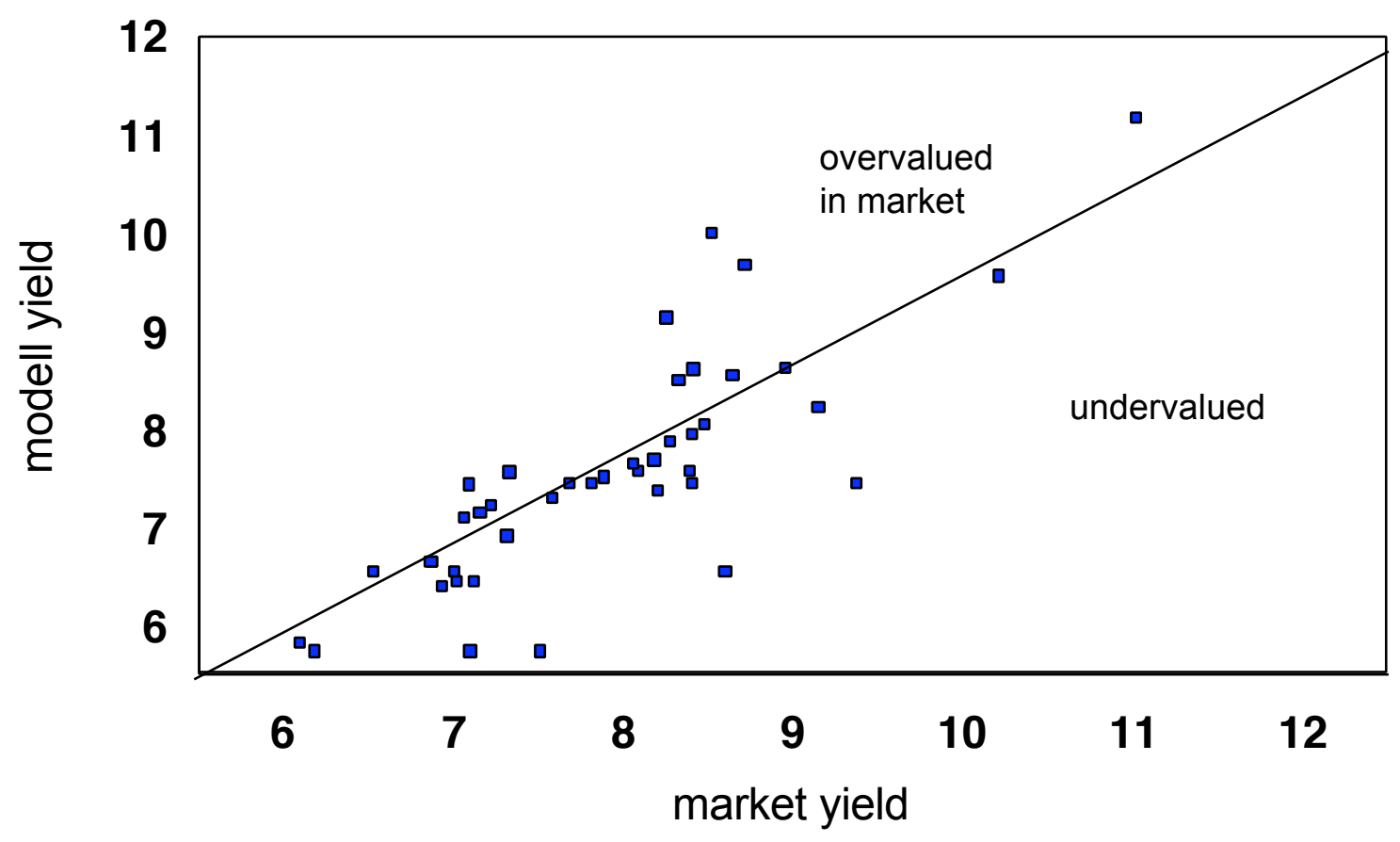

Finsbury Smaller excluded: market yield of $15.0 \%$ 
Figure 11: Model Yield v. Market Yield in June 2000

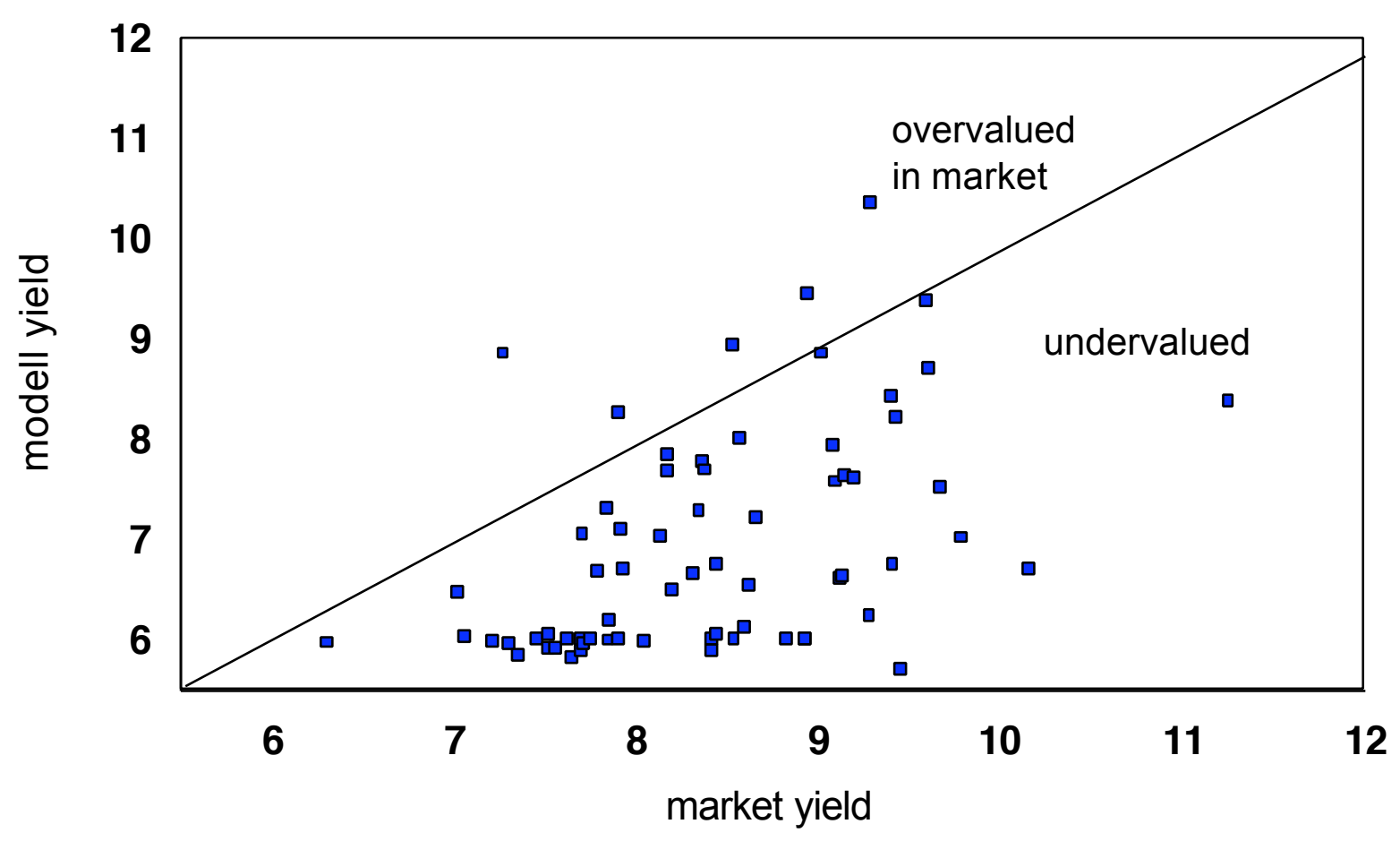

Figure 12: Model "Errors" and the Premium on Closed-End Funds

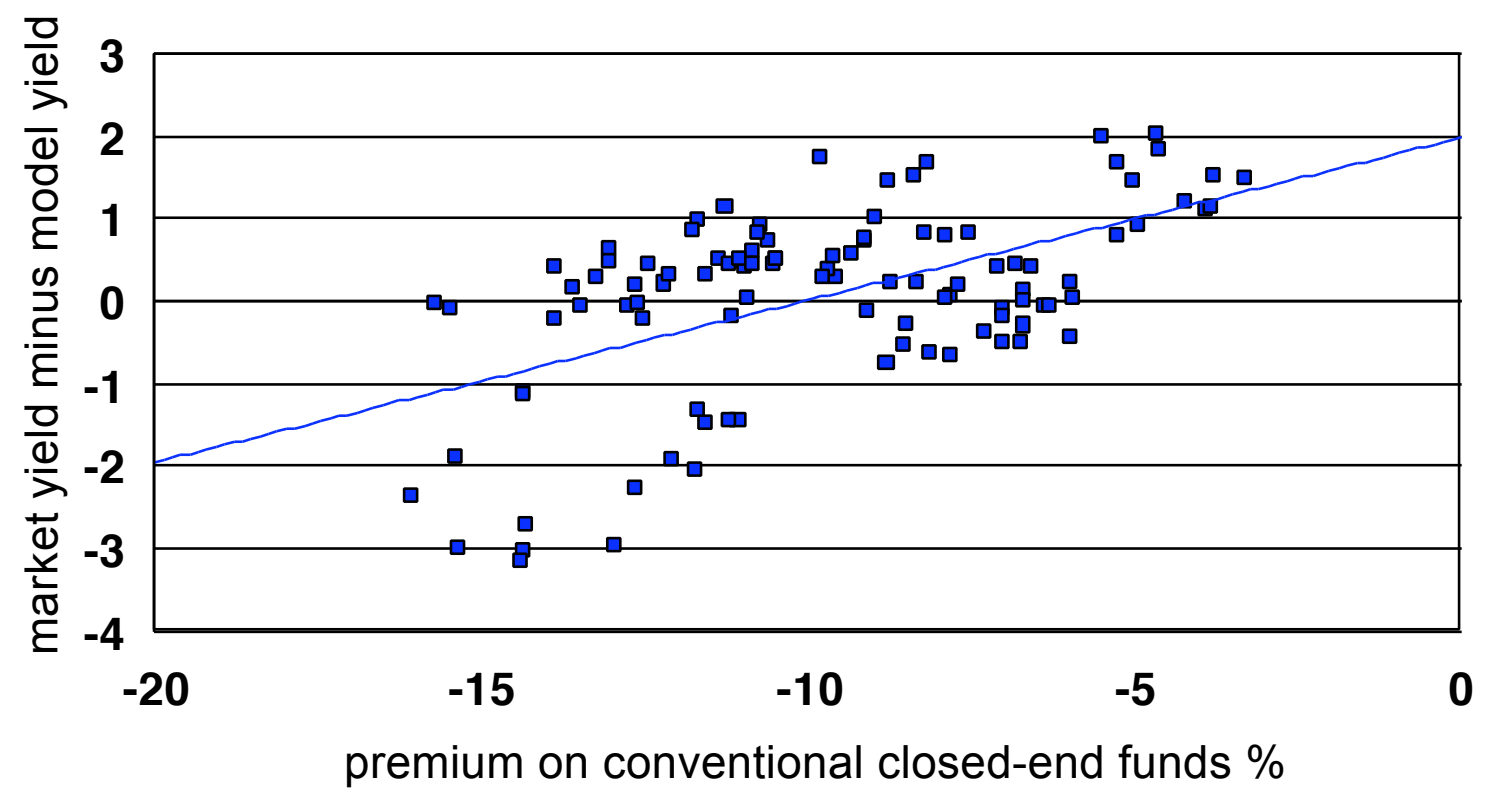


Figure 13: Model "Errors" and Market Volatility

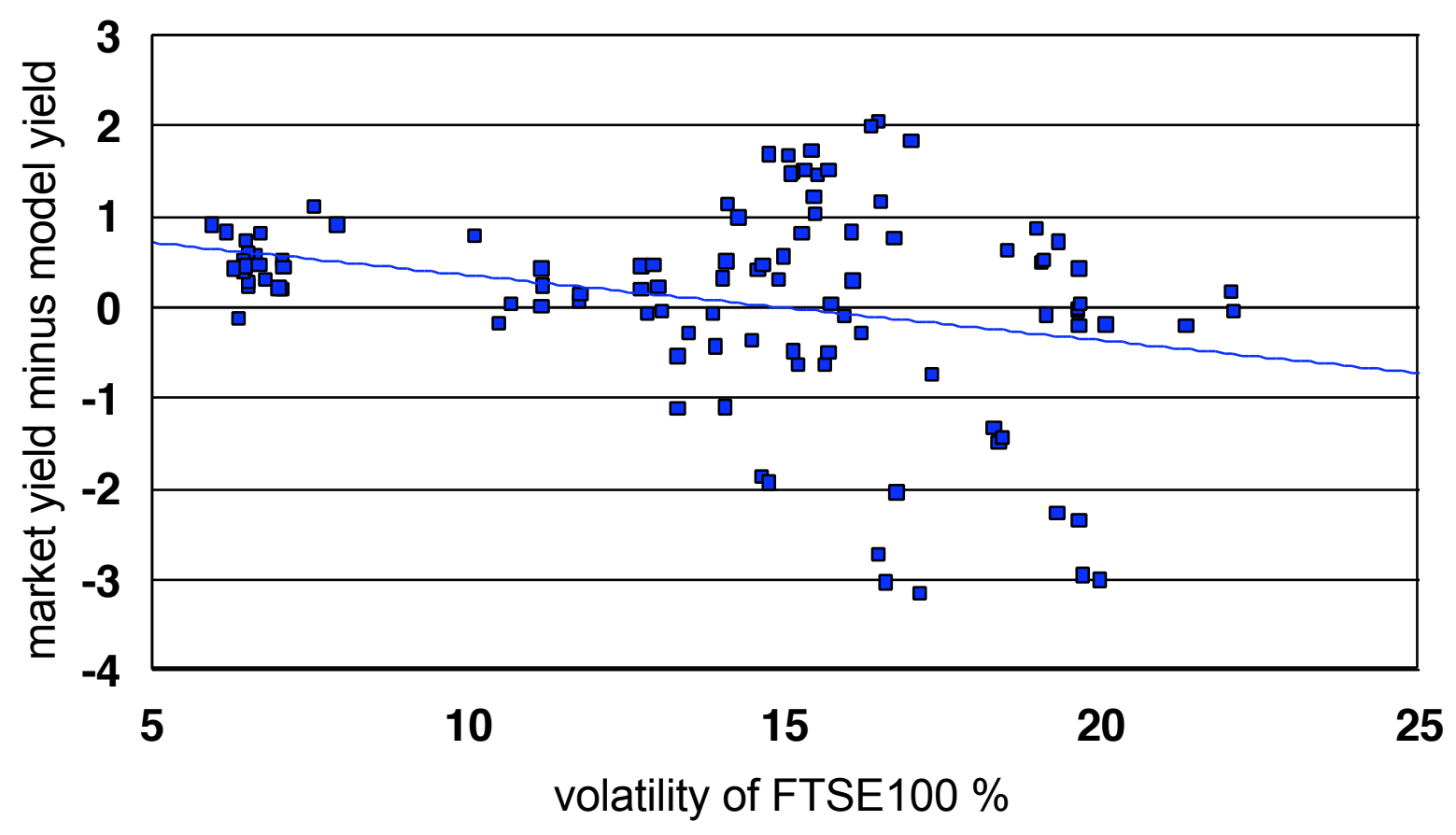




\section{List of other working papers:}

\section{2}

1. Paolo Zaffaroni, Gaussian inference on Certain Long-Range Dependent Volatility Models, WP02-12

2. Paolo Zaffaroni, Aggregation and Memory of Models of Changing Volatility, WP02-11

3. Jerry Coakley, Ana-Maria Fuertes and Andrew Wood, Reinterpreting the Real Exchange Rate - Yield Diffential Nexus, WP02-10

4. Gordon Gemmill and Dylan Thomas, Noise Training, Costly Arbitrage and Asset Prices: evidence from closed-end funds, WP02-09

5. Gordon Gemmill, Testing Merton's Model for Credit Spreads on Zero-Coupon Bonds, WP0208

6. George Christodoulakis and Steve Satchell, On th Evolution of Global Style Factors in the MSCI Universe of Assets, WP02-07

7. George Christodoulakis, Sharp Style Analysis in the MSCI Sector Portfolios: A Monte Caro Integration Approach, WP02-06

8. George Christodoulakis, Generating Composite Volatility Forecasts with Random Factor Betas, WP02-05

9. Claudia Riveiro and Nick Webber, Valuing Path Dependent Options in the Variance-Gamma Model by Monte Carlo with a Gamma Bridge, WP02-04

10. Christian Pedersen and Soosung Hwang, On Empirical Risk Measurement with Asymmetric Returns Data, WP02-03

11. Roy Batchelor and Ismail Orgakcioglu, Event-related GARCH: the impact of stock dividends in Turkey, WP02-02

12. George Albanis and Roy Batchelor, Combining Heterogeneous Classifiers for Stock Selection, WP02-01

\section{1}

1. Soosung Hwang and Steve Satchell, GARCH Model with Cross-sectional Volatility; GARCHX Models, WP01-16

2. Soosung Hwang and Steve Satchell, Tracking Error: Ex-Ante versus Ex-Post Measures, WP01-15

3. Soosung Hwang and Steve Satchell, The Asset Allocation Decision in a Loss Aversion World, WP01-14

4. Soosung Hwang and Mark Salmon, An Analysis of Performance Measures Using Copulae, WP01-13

5. Soosung Hwang and Mark Salmon, A New Measure of Herding and Empirical Evidence, WP01-12

6. Richard Lewin and Steve Satchell, The Derivation of New Model of Equity Duration, WP0111

7. Massimiliano Marcellino and Mark Salmon, Robust Decision Theory and the Lucas Critique, WP01-10

8. Jerry Coakley, Ana-Maria Fuertes and Maria-Teresa Perez, Numerical Issues in Threshold Autoregressive Modelling of Time Series, WP01-09

9. Jerry Coakley, Ana-Maria Fuertes and Ron Smith, Small Sample Properties of Panel Timeseries Estimators with I(1) Errors, WP01-08

10. Jerry Coakley and Ana-Maria Fuertes, The Felsdtein-Horioka Puzzle is Not as Bad as You Think, WP01-07

11. Jerry Coakley and Ana-Maria Fuertes, Rethinking the Forward Premium Puzzle in a Nonlinear Framework, WP01-06

12. George Christodoulakis, Co-Volatility and Correlation Clustering: A Multivariate Correlated ARCH Framework, WP01-05 
13. Frank Critchley, Paul Marriott and Mark Salmon, On Preferred Point Geometry in Statistics, WP01-04

14. Eric Bouyé and Nicolas Gaussel and Mark Salmon, Investigating Dynamic Dependence Using Copulae, WP01-03

15. Eric Bouyé, Multivariate Extremes at Work for Portfolio Risk Measurement, WP01-02

16. Erick Bouyé, Vado Durrleman, Ashkan Nikeghbali, Gael Riboulet and Thierry Roncalli, Copulas: an Open Field for Risk Management, WP01-01

\section{0}

1. Soosung Hwang and Steve Satchell, Valuing Information Using Utility Functions, WP00-06

2. Soosung Hwang, Properties of Cross-sectional Volatility, WP00-05

3. Soosung Hwang and Steve Satchell, Calculating the Miss-specification in Beta from Using a Proxy for the Market Portfolio, WP00-04

4. Laun Middleton and Stephen Satchell, Deriving the APT when the Number of Factors is Unknown, WP00-03

5. George A. Christodoulakis and Steve Satchell, Evolving Systems of Financial Returns: AutoRegressive Conditional Beta, WP00-02

6. Christian S. Pedersen and Stephen Satchell, Evaluating the Performance of Nearest Neighbour Algorithms when Forecasting US Industry Returns, WP00-01

\section{9}

1. Yin-Wong Cheung, Menzie Chinn and Ian Marsh, How do UK-Based Foreign Exchange Dealers Think Their Market Operates?, WP99-21

2. Soosung Hwang, John Knight and Stephen Satchell, Forecasting Volatility using LINEX Loss Functions, WP99-20

3. Soosung Hwang and Steve Satchell, Improved Testing for the Efficiency of Asset Pricing Theories in Linear Factor Models, WP99-19

4. Soosung Hwang and Stephen Satchell, The Disappearance of Style in the US Equity Market, WP99-18

5. Soosung Hwang and Stephen Satchell, Modelling Emerging Market Risk Premia Using Higher Moments, WP99-17

6. Soosung Hwang and Stephen Satchell, Market Risk and the Concept of Fundamental Volatility: Measuring Volatility Across Asset and Derivative Markets and Testing for the Impact of Derivatives Markets on Financial Markets, WP99-16

7. Soosung Hwang, The Effects of Systematic Sampling and Temporal Aggregation on Discrete Time Long Memory Processes and their Finite Sample Properties, WP99-15

8. Ronald MacDonald and Ian Marsh, Currency Spillovers and Tri-Polarity: a Simultaneous Model of the US Dollar, German Mark and Japanese Yen, WP99-14

9. Robert Hillman, Forecasting Inflation with a Non-linear Output Gap Model, WP99-13

10. Robert Hillman and Mark Salmon, From Market Micro-structure to Macro Fundamentals: is there Predictability in the Dollar-Deutsche Mark Exchange Rate?, WP99-12

11. Renzo Avesani, Giampiero Gallo and Mark Salmon, On the Evolution of Credibility and Flexible Exchange Rate Target Zones, WP99-11

12. Paul Marriott and Mark Salmon, An Introduction to Differential Geometry in Econometrics, WP99-10

13. Mark Dixon, Anthony Ledford and Paul Marriott, Finite Sample Inference for Extreme Value Distributions, WP99-09

14. Ian Marsh and David Power, A Panel-Based Investigation into the Relationship Between Stock Prices and Dividends, WP99-08

15. Ian Marsh, An Analysis of the Performance of European Foreign Exchange Forecasters, WP99-07

16. Frank Critchley, Paul Marriott and Mark Salmon, An Elementary Account of Amari's Expected Geometry, WP99-06

17. Demos Tambakis and Anne-Sophie Van Royen, Bootstrap Predictability of Daily Exchange Rates in ARMA Models, WP99-05

18. Christopher Neely and Paul Weller, Technical Analysis and Central Bank Intervention, WP9904

19. Christopher Neely and Paul Weller, Predictability in International Asset Returns: A Reexamination, WP99-03 
20. Christopher Neely and Paul Weller, Intraday Technical Trading in the Foreign Exchange Market, WP99-02

21. Anthony Hall, Soosung Hwang and Stephen Satchell, Using Bayesian Variable Selection Methods to Choose Style Factors in Global Stock Return Models, WP99-01

\section{8}

1. Soosung Hwang and Stephen Satchell, Implied Volatility Forecasting: A Compaison of Different Procedures Including Fractionally Integrated Models with Applications to UK Equity Options, WP98-05

2. Roy Batchelor and David Peel, Rationality Testing under Asymmetric Loss, WP98-04

3. Roy Batchelor, Forecasting T-Bill Yields: Accuracy versus Profitability, WP98-03

4. Adam Kurpiel and Thierry Roncalli, Option Hedging with Stochastic Volatility, WP98-02

5. Adam Kurpiel and Thierry Roncalli, Hopscotch Methods for Two State Financial Models, WP98-01 